\title{
Effects of membrane depolarization on intracellular calcium in single nerve terminals
}

\author{
Edward L. Stuenkel \\ Department of Physiology, University of Michigan, Ann Arbor, MI 48109 (U.S.A.)
}

(Accepted 27 March 1990)

Key words: Nerve ending; Neurohypophysis; $\mathrm{Ca}^{2+}$ fura-2; $\mathrm{Ca}^{2+}$ channel; Cholecystokinin; Relaxin

\begin{abstract}
The $\left[\mathrm{Ca}^{2+}\right]_{\mathrm{i}}$ of individual neurosecretory nerve terminals loaded with the fluorescent probe fura- 2 was monitored during depolarizing stimuli and in the presence of substances known to induce or block neurohormone release. Induction of membrane depolarization with elevated [ $\mathrm{K}^{+}$] or veratridine led to a rapid increase in $\left[\mathrm{Ca}^{2+}\right]_{\mathrm{i}}$ that was sensitive to block by substances which block voltage-sensitive $\mathrm{L}_{\text {-type }} \mathrm{Ca}^{2+}$ channels such as the dihydropyridine nicardipine and by D-888. Relaxin, cholecystokinin and enkephalin which have been reported to regulate vasopressin and oxytocin secretion at the nerve endings were without effect on basal $\left[\mathrm{Ca}^{2+}\right]_{i}$ or $\mathrm{K}^{+}$-stimulated increases in $\left[\mathrm{Ca}^{2+}\right]_{j}$.
\end{abstract}

\section{INTRODUCTION}

Neurotransmitter or neurohormone secretion from nerve endings relies on entry of extracellular $\mathrm{Ca}^{2+}$ which results from changes in membrane potential and activation of voltage-sensitive $\mathrm{Ca}^{2+}$ channels. Limitations imposed by the size of most vertebrate nerve endings, however, have largely precluded characterization of $\mathrm{Ca}^{2+}$ entry, the rise in intraterminal $\mathrm{Ca}^{2+}$ concentration $\left(\left[\mathrm{Ca}^{2+}\right]_{\mathrm{i}}\right)$, and of the mechanisms of $\mathrm{Ca}^{2+}$ sequestration and efflux at single nerve endings. Therefore, much of the current understanding of these processes comes from studies of the invertebrate squid giant synapse $e^{1,6,14,17}$ and radioactive tracer studies in synaptosomal preparations in vertebrate nerve endings ${ }^{19,21,28,32}$. Recently, development of the $\mathrm{Ca}^{2+}$-sensitive fluorescent probes have allowed characterization of $\left[\mathrm{Ca}^{2+}\right]_{i}$ and of depolarization induced changes in $\left[\mathrm{Ca}^{2+}\right]_{i}$ in vertebrate synaptosomal ${ }^{12}$, $20,23,34$ and neurosecretory endings ${ }^{4}$. To date, however, their use has been restricted to populations of nerve endings in a fluorometer cuvette under static conditions. There are several problems associated with this populational approach. For synaptosomal preparations homogeneity with respect to the nerve ending type is not assured nor are postsynaptic and glial elements necessarily eliminated leading to measurements which reflect an integrated response and thereby masking differences between neurotransmitter ending types. Furthermore, the static conditions do not allow for substance applica- tion and removal nor for washout of dye effluxed from the cells during the measurements. The present study utilizes dual wavelength microspectrofluorometry of fura2 to monitor changes in $\left[\mathrm{Ca}^{2+}\right]_{i}$ in individual superfused neurosecretory nerve terminals stimulated with substances known to induce or block neurohormone release. The preparation consists entirely of nerve endings isolated from the neural lobe without contribution from post-synaptic membrane and which retain $\mathrm{Ca}^{2+}$-dependent secretory responsiveness as detailed by Nordmann and coworkers ${ }^{5,25}$.

\section{MATERIALS AND METHODS}

Isolated nerve endings were prepared from neurohypophyses of male Sprague-Dawley rats $(200-250 \mathrm{~g})$ using a modification of the procedure detailed by Nordmann ${ }^{5,25}$. The pars intermedia was removed from the neurohypophysis and the neural lobe homogenized in a buffer at $37^{\circ} \mathrm{C}$ containing: $270 \mathrm{mM}$ sucrose, $10 \mu \mathrm{M}$ EGTA, $1 \mathrm{mM}$ phenylmethylsulfonyl fluoride, $1 \mathrm{mM}$ benzamidine, $10 \mathrm{mM}$ HEPES buffered to pH 7.2 with Tris. The homogenate was then centrifuged in an Eppendorf microcentrifuge for $1.5 \mathrm{~min}$. Following centrifugation the supernatant was discarded and the pellet resuspended in $0.5 \mathrm{ml}$ of physiological saline at $37^{\circ} \mathrm{C}$ containing: $135 \mathrm{mM} \mathrm{NaCl}, 5 \mathrm{mM} \mathrm{KCl}, 1 \mathrm{mM} \mathrm{MgCl}, 2.2 \mathrm{mM} \mathrm{CaCl}$, $10 \mathrm{mM}$ glucose buffered to $\mathrm{pH} 7.2$ with $10 \mathrm{mM}$ NaOH-HEPES. The endings were incubated for $30 \mathrm{~min}$ at $37^{\circ} \mathrm{C}$ with $3 \mu \mathrm{M}$ fura-2/AM followed by centrifugation to remove extracellular dye $(0.5 \mathrm{~min})$ and resuspension in the physiological saline.

Solutions of elevated $\left[\mathrm{K}^{+}\right]$were prepared by equimolar substitution with $\left[\mathrm{Na}^{+}\right]$in the physiological saline. Reductions in $\mathrm{Na}^{+}$alone by equimolar substitution with $N$-methyl-D-glucamine $\left(\mathrm{NMG}^{+}\right)$ showed no effect on $\left[\mathrm{Ca}^{2+}\right]_{\mathrm{i}}$. Stock solutions of nicardipine were prepared in DMSO, [D-Ala ${ }^{2 \cdot}$-Leu $\left.{ }^{5}\right]$ enkephalin, relaxin and chole-

Correspondence: E.L. Stuenkel, Department of Physiology, University of Michigan, 7744 Medical Sciences II Building, Ann Arbor, MI 48109-0622, U.S.A. 
cystokinin (CCK-8) in distilled water with $0.01 \%$ bovine serum albumin and veratridine in ethanol. Dilution of each substance into physiological saline was performed just prior to use. All solutions containing peptides also contained $0.05 \%$ BSA as carrier. Relaxin was a gift of the National Hormone and Pituitary Program, University of Maryland School of Medicine.

Determination of $\left[\mathrm{Ca}^{2+}\right]_{i}$ in individual nerve endings was determined by dual wavelength microspectrofluorometry following loading with fura-2/AM. The microspectrofluorometry equipment and superfusion chamber utilized to monitor $\left[\mathrm{Ca}^{2+}\right]_{i}$ in individual nerve endings was identical to that previously described on single cells ${ }^{30,31}$. All measurements were performed at $37^{\circ} \mathrm{C}$ in a chamber providing rapid exchange of the superfusing physiological saline. The fluorescence ratio was converted to $\left[\mathrm{Ca}^{2+}\right]_{i}$ using the equation of Grynkiewicz et al. ${ }^{11}$. Values of $R_{\min }, R_{\max }$ and $F_{\mathrm{o}} / F_{\mathrm{s}}$ were determined using an external standard calibration technique ${ }^{7}$ resulting in values of $0.77,19.3$, and 5.5 respectively. A $K_{d}$ value for fura-2 of $225 \mathrm{nM}$ was taken from the literature ${ }^{11}$. Traces shown in the figures are representative of at least 3 separate determinations.

\section{RESULTS}

The changes in $\left[\mathrm{Ca}^{2+}\right]_{i}$ in individual nerve endings were examined using elevated concentrations of $\mathrm{K}^{+}$in the physiological saline to induce depolarization of the membrane potential and activation of voltage-sensitive $\mathrm{Ca}^{2+}$ channels. The $\left[\mathrm{K}^{+}\right]$utilized $(25-50 \mathrm{mM})$ has previously been shown to evoke submaximal $\mathrm{Ca}^{2+}$. dependent secretion of vasopressin and oxytocin in the isolated neural lobe endings ${ }^{5}$. The mean basal $\left[\mathrm{Ca}^{2+}\right]_{i}$ value for individual fura-2 loaded terminals in the present study was $73 \pm 4 \mathrm{nM}(n=126, \pm$ S.E.M. $)$. Depolarization of the endings with $25 \mathrm{mM}$ or $50 \mathrm{mM} \mathrm{K}^{+}$resulted in an increase in $\left[\mathrm{Ca}^{2+}\right]_{\mathrm{i}}$ of $87 \pm 7 \mathrm{nM}(n=24)$ and 205 $\pm 18 \mathrm{nM}(n=64)$, respectively. In all cases application of elevated $\left[\mathrm{K}^{+}\right]$led to a rapid increase in $\left[\mathrm{Ca}^{2+}\right]_{i}$ which was maintained for the duration of the pulse. Recovery of $\left[\mathrm{Ca}^{2+}\right]_{\mathrm{i}}$ to basal values on washout of the elevated $\left[\mathrm{K}^{+}\right]$ required several minutes. Fig. 1 shows representative responses from individual terminals to pulses of $50 \mathrm{mM}$ $\mathrm{K}^{+}$. The rapid rise in intraterminal $\left[\mathrm{Ca}^{2+}\right]$ to elevated $\left[\mathrm{K}^{+}\right]$was clearly dependent on influx of $\mathrm{Ca}^{2+}$ as the response was nearly completely blocked in $\mathrm{Ca}^{2+}$-free media (no added $\mathrm{Ca}^{2+}$ plus $1 \mathrm{mM}$ EGTA) and significantly reduced by $100 \mu \mathrm{M} \mathrm{CdCl}_{2} \cdot \mathrm{Ca}^{2+}$-free medium alone reduced basal $\left[\mathrm{Ca}^{2+}\right]_{i}$ values only slightly. Sustained superfusion with $\mathrm{Ca}^{2+}$-free medium $(20 \mathrm{~min})$ and subsequent application of ionomycin $(10 \mu \mathrm{M})$ results in a large increase in intraterminal $\mathrm{Ca}^{2+}$ arising from release from intraterminal stores (data not shown). Hence, $\mathrm{Ca}^{2+}$-free medium does not deplete intracellular $\mathrm{Ca}^{2+}$. Furthermore, no difference in the $\mathrm{K}^{+}$-induced increase in $\left[\mathrm{Ca}^{2+}\right]_{\mathrm{i}}$ or in recovery was observed in $\mathrm{Na}^{+}$-free medium (Fig. 1C).

Monitoring $\left[\mathrm{Ca}^{2+}\right]_{i}$ in an individual nerve ending during regimes of repetitive stimulation (see Fig. 1B) allowed the effects of various $\mathrm{Ca}^{2+}$ channel agonists and antagonists to be quantitated with respect to a control stimulation. Furthermore, this approach allowed recovery of responsiveness to be assessed following removal of the agonist or antagonist. In particular, the increases in $\left[\mathrm{Ca}^{2+}\right]_{\mathrm{i}}$ induced by $50 \mathrm{mM}\left[\mathrm{K}^{+}\right]$alone, in the presence of $100 \mu \mathrm{M} \mathrm{Cd}^{2+}$ and following washout of $\mathrm{Cd}^{2+}$ were $365 \pm$ $114,66 \pm 15$, and $350 \pm 107 \mathrm{nM}(n=4)$, respectively. The data confirm the potent inhibitory effect of $\mathrm{Cd}^{2+}$ as a blocker of voltage-sensitive $\mathrm{Ca}^{2+}$ channels.

Several types of voltage-sensitive $\mathrm{Ca}^{2+}$ channels are distinguishable by biophysical and pharmacological characteristics in the somata of neurons ${ }^{18}$ and in muscle cells ${ }^{2}$. One of these channels termed 'L-type' characteristically shows sensitivity to dihydropyridines (DHP) while the other types lack such sensitivity ${ }^{26}$. Fig. 2 shows the response of individual nerve endings to the DHP, nicardipine which blocks oxytocin and vasopressin secretion ${ }^{5}$. Nicardipine induced a dose-dependent inhibition of the $\left[\mathrm{K}^{+}\right]$induced increase in $\left[\mathrm{Ca}^{2+}\right]_{i}$ (Fig. 2C) although a slight increase could still be resolved in each terminal examined at a concentration of $25 \mu \mathrm{M}$ nicardipine. Averaged results for the increase in $\left[\mathrm{Ca}^{2+}\right]_{i}$ by two control $\mathrm{K}^{+}$challenges and a third elevated $\left[\mathrm{K}^{+}\right]$pulse with $5 \mu \mathrm{M}$ nicardipine present are $166 \pm 34,173 \pm 36$, $51 \pm 12 \mathrm{nM}(n=9)$, respectively. Mean resuls for an identical regime but with $25 \mu \mathrm{M}$ nicardipine were $199 \pm$

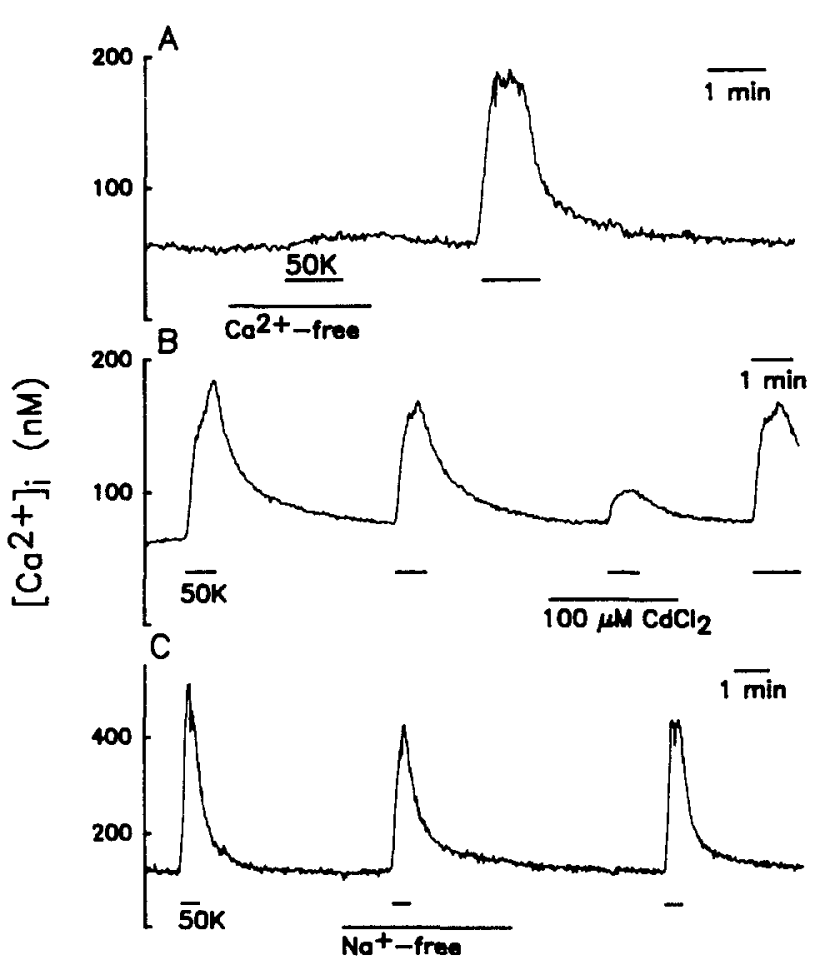

Fig. 1. Effect of $\mathrm{K}^{+}$-induced depolarization on $\left[\mathrm{Ca}^{2+}\right]_{i}$ in single nerve terminals. The $\mathrm{K}^{+}$-induced $(50 \mathrm{mM})$ rise in $\left[\mathrm{Ca}^{2+}\right]_{i}$ is dependent on extracellular $\mathrm{Ca}^{2+}(\mathrm{A})$ significantly reduced by $\mathrm{Cd}^{2+}$ (B) and unaffected by complete replacement of $\mathrm{Na}^{+}$by $\mathrm{NMG}^{+}(\mathrm{C})$. 

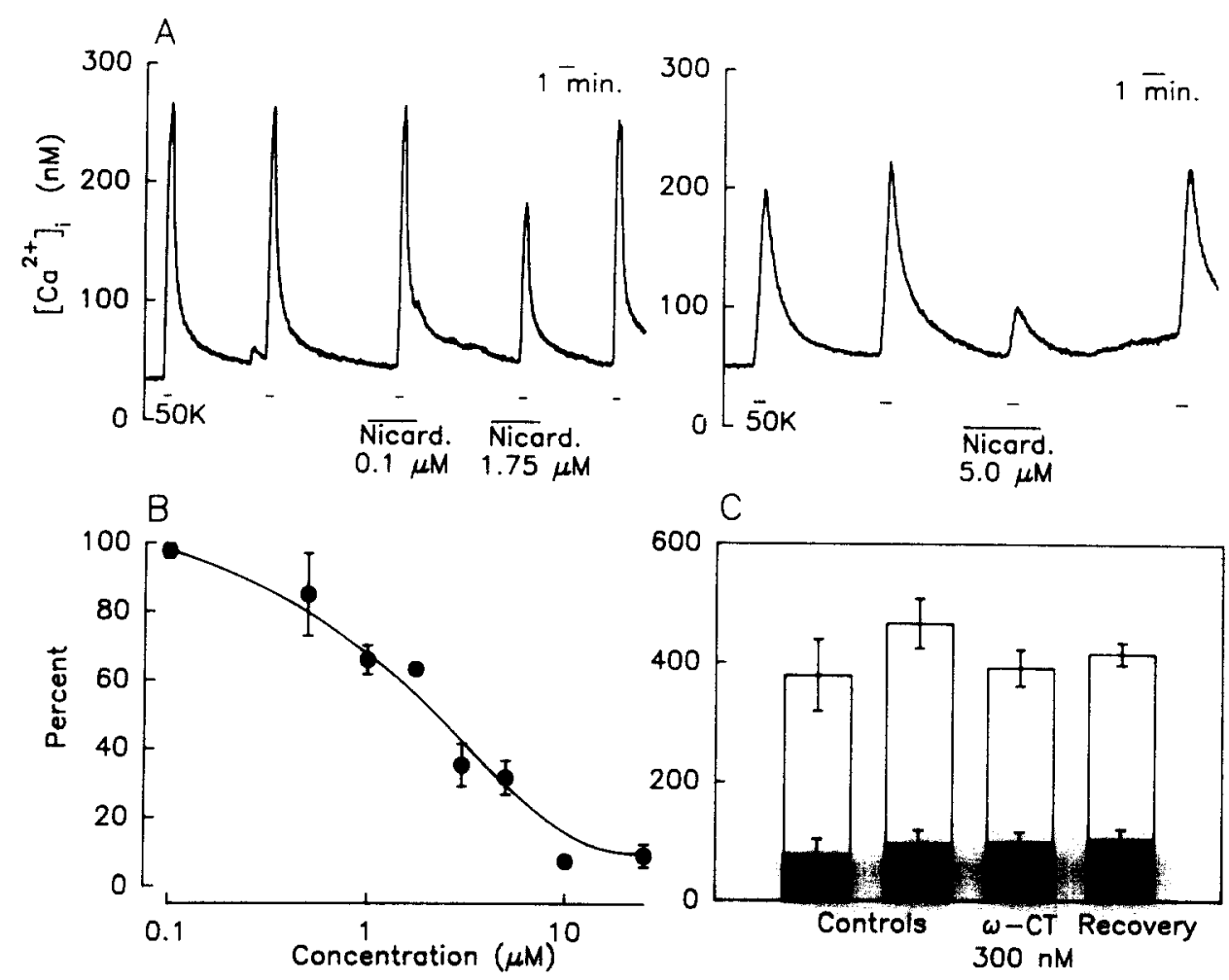

Fig. 2. Effect of the DHP nicardipine and of $\omega$-conotoxin GVIA on $50 \mathrm{mM} \mathrm{K}{ }^{+}$-induced increases in $\left[\mathrm{Ca}^{2+}\right]_{\mathrm{j}}$. A: addition of nicardipine prior to and during $\mathrm{K}^{+}$-induced depolarization inhibits the evoked increase in $\left[\mathrm{Ca}^{2+}\right]_{\mathrm{i}}$. Subsequent washout of both elevated $\mathrm{K}^{+}$and nicardipine and restimulation with $\mathrm{K}^{+}$alone shows recovery of the $\mathrm{K}^{+}$-induced increase in $\left[\mathrm{Ca}^{2+}\right]_{\mathrm{i}}$. Data shown from two separate endings. $\mathrm{B}$ : the effects of increasing concentrations of nicardipine on $\mathrm{K}^{+}$-evoked $\left[\mathrm{Ca}^{2+}\right]_{\mathrm{i}}$ increase. Data for each nicardipine concentration are expressed as a percentage of the response under control conditions. Two control $\mathrm{K}^{+}$-stimulations from which an average $\left[\mathrm{Ca}^{2+}\right]_{\mathrm{i}}$ was determined preceded each test stimulation in the presence of nicardipine. Values from at least 3 individual endings constitute each data point. $\mathrm{C}$ : the effect of $\omega$-conotoxin $(n=5)$ on basal $\left[\mathrm{Ca}^{2+}\right]_{\mathrm{i}}$ (solid bars) and on a $\mathrm{K}^{+}$-induced $\left[\mathrm{Ca}^{2+}\right]_{\mathrm{i}}$ increase (open bars).

$45,178 \pm 28,13 \pm 3 \mathrm{nM}(n=6)$, respectively. No effect of nicardipine was observed on basal $\left[\mathrm{Ca}^{2+}\right]_{i}$ values. The effects of nicardipine were fully reversible.

The peptide toxin $\omega$-conotoxin GVIA, which blocks two distinct $\mathrm{Ca}^{2+}$ channel types ( $\mathrm{L}$ and $\mathrm{N}$ ) in chick sensory neurons ${ }^{10}$ exhibits saturable binding and potently inhibits $\mathrm{K}^{+}$-induced vasopressin release from the isolated neural lobe nerve endings ${ }^{9}$. The effects of $\omega$-conotoxin were therefore tested on the $\mathrm{K}$-evoked $\left[\mathrm{Ca}^{2+}\right]_{i}$ increase. Application of $\omega$-conotoxin GVIA at concentrations showing near maximal inhibition of $\mathbf{K}$-induced vasopressin release $(300 \mathrm{nM})$, however, showed no effect on basal $\left[\mathrm{Ca}^{2+}\right]_{\mathrm{i}}$ or on a $50 \mathrm{mM} \mathrm{K}{ }^{+}$-induced increase in $\left[\mathrm{Ca}^{2+}\right]_{i}$ (Fig. 2C). In comparison, D-888 (desmethoxyverapamil) which also blocks voltage-dependent $\mathrm{Ca}^{2+}$ channels and neurohormone secretion ${ }^{9}$ effectively reduced the $\mathrm{K}^{+}$. evoked $\left[\mathrm{Ca}^{2+}\right]_{\mathrm{i}}$ increase. D-888 at a concentration (25 $\mu \mathrm{M})$ which reduces vasopressin secretion by greater than $85 \%$ reduced the $\mathrm{K}$-induced increase in $\left[\mathrm{Ca}^{2+}\right]_{\mathrm{i}}$ by $87 \%$ $(n=4)$ without itself affecting basal $\left[\mathrm{Ca}^{2+}\right]_{\mathrm{i}}$. The inhibition by $\mathrm{D}-888$ was completely reversible.

An alternate approach to depolarize nerve endings and thereby induce $\mathrm{Ca}^{2+}$ entry and secretion is to utilize veratridine which maintains voltage-dependent $\mathrm{Na}^{+}$
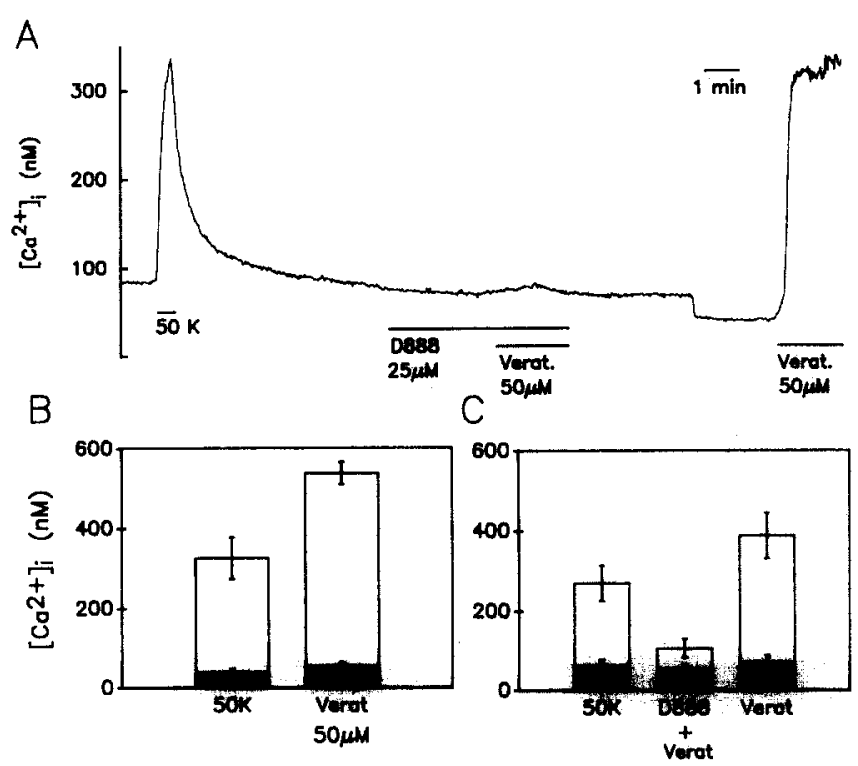

Fig. 3. Effect of veratridine on $\left[\mathrm{Ca}^{2+}\right]_{1}$. A: representative recording of veratridine $(50 \mu \mathrm{M})$ induced $\left[\mathrm{Ca}^{2+}\right]_{\mathrm{i}}$ increase and block of the effect by pretreatment with $25 \mu \mathrm{M}$ D-888. B: averaged results $(n=$ 4) comparing increase in $\left[\mathrm{Ca}^{2+}\right]_{\mathrm{i}}$ resulting from $50 \mathrm{mM} \mathrm{K}{ }^{+}(0.5 \mathrm{~min})$ stimulation with that induced by $50 \mu \mathrm{M}$ veratridine. C: averaged results of D-888 block of the veratridine response and comparison to a subsequent application of veratridine alone $(n=4)$. Solid and open bars in $B$ and $C$ represent basal and stimulated values, respectively. 


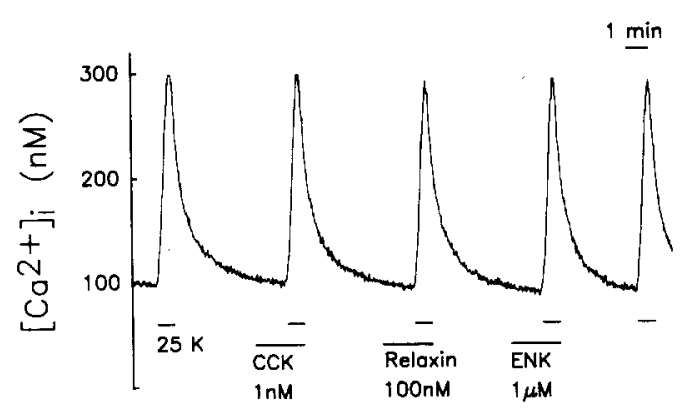

Fig. 4. Effects on $\left[\mathrm{Ca}^{2+}\right]_{i}$ of relaxin, CCK and enkephalin. Representative recording of $25 \mathrm{mM} \mathrm{K}^{+}$-induced increases in $\left[\mathrm{Ca}^{2+}\right]_{\mathrm{i}}$ from an individual terminal showing the lack of effect on basal or stimulated $\left[\mathrm{Ca}^{2+}\right]_{i}$ values.

channels in an activated state $e^{4,25,27}$. Fig. 3 shows a representative example of the effects of veratridine on an individual nerve ending. Veratridine produced a rapid maintained increase in $\left[\mathrm{Ca}^{2+}\right]_{i}$ which was generally greater in amplitude than that induced by a 0.5 -min pulse of $50 \mathrm{mM}\left[\mathrm{K}^{+}\right]$(Fig. 3B). Prior application of D-888 effectively blocked the entry of $\mathrm{Ca}^{2+}$ arising from the depolarization induced by veratridine (Fig. 3A,C). Nicardipine $(25 \mu \mathrm{M})$ added prior and during veratridine application was also effective at reducing the depolarization-induced increase in $\left[\mathrm{Ca}^{2+}\right]_{\mathrm{i}}$.

A number of peptides have been suggested to exert a regulatory influence on $\left[\mathrm{Ca}^{2+}\right]_{i}$ in the neural lobe nerve endings based on their effects to potentiate or reduce oxytocin or vasopressin secretion. The effects of 3 of these compounds at doses which exert maximal effects on secretion are shown in Fig. 4. Relaxin, which reduces basal but potentiates both electrical and $\mathrm{K}^{+}$-evoked secretion ${ }^{8}$ showed no effect either on basal $\left[\mathrm{Ca}^{2+}\right]_{i}$ or a $25 \mathrm{mM} \mathrm{K}^{+}(n=4)$ or $50 \mathrm{mM} \mathrm{K}^{+}(n=4)$ induced increase in $\left[\mathrm{Ca}^{2+}\right]_{\mathrm{i}}$. Cholecystokinin (CCK) has recently been suggested to induce mobilization of $\mathrm{Ca}^{2+}$ from intraterminal stores and thereby evoke secretion even in the absence of electrical or $\mathrm{K}$-induced stimulation ${ }^{3}$. However, no effect of CCK at 1 or $10 \mathrm{nM}$ on basal $\left[\mathrm{Ca}^{2+}\right]_{i}$ or on $25 \mathrm{mM} \mathrm{K}^{+}$-stimulated increase in $\left[\mathrm{Ca}^{2+}\right]_{\mathrm{i}}(n=4)$ was observed. Prolonged application of CCK (1 nM, $25 \mathrm{~min})$, also showed no effects on $\left[\mathrm{Ca}^{2+}\right]_{i}$ (data not shown). No effect of enkephalin, which has also been suggested in some studies to regulate secretion from these endings (see ref. 24 for review), on either basal $\left[\mathrm{Ca}^{2+}\right]_{i}$ or on 25 $\mathrm{mM} \mathrm{K}{ }^{+}$-stimulated increase in $\left[\mathrm{Ca}^{2+}\right]_{i}(n=3)$ was observed.

\section{DISCUSSION}

The present study demonstrates the applicability of quantitatively characterizing in individual nerve terminals, loaded with the $\mathrm{Ca}^{2+}$-sensitive fluorescent indicator fura-2, changes in $\left[\mathrm{Ca}^{2+}\right]_{i}$ resulting from stimulation. This approach overcomes the masking of differences between nerve ending types and of contributions from nonpresynaptic terminal membrane as occurs when properties of $\mathrm{Ca}^{2+}$ influx or rise in intraterminal $\left[\mathrm{Ca}^{2+}\right]$ are characterized on a population of terminals. Comparison of the results from the present study with those from fura-2 measurements on a population of neural lobe endings ${ }^{4}$ show differences which likely result from the increased sensitivity of the individual terminal approach. These include a much lower value for basal $\left[\mathrm{Ca}^{2+}\right]_{i}$ (i.e. $73 \mathrm{nM})$ than previously reported $(350-420 \mathrm{nM})$ and the lack of a substantial reduction in $\left[\mathrm{Ca}^{2+}\right]_{\mathrm{i}}$ by removing extracellular $\mathrm{Ca}^{2+}$. In addition, nicardipine which produced a complete block of the $\mathrm{K}^{+}$-stimulated increase in $\left[\mathrm{Ca}^{2+}\right]_{i}$ in the populational study produced a significant but incomplete block at the single terminal level. Although the modest increases in $\left[\mathrm{Ca}^{2+}\right]_{i}$ to $\mathrm{K}^{+}$-induced depolarization could be representative of heavy loading of fura-2 several observations suggest this not to be the case. These include: (1) a rapid rate of rise in $\left[\mathrm{Ca}^{2+}\right]_{i}$ on addition of elevated $\left[\mathrm{K}^{+}\right]$, (2) a rapid and complete recovery of $\left[\mathrm{Ca}^{2+}\right]_{\mathrm{i}}$ following stimulation; (3) a similar increase in $\left[\mathrm{Ca}^{2+}\right]_{i}$ to repetitive pulses of elevated $\left[\mathrm{K}^{+}\right]$ and (4) a moderate absolute fluorescent intensity and an estimate of basal $\left[\mathrm{Ca}^{2+}\right]_{i}$ similar to that reported for most excitable and non-excitable cells.

The nerve endings of the neural lobe represent only two classes of endings: those arising from vasopressin or oxytocin neurons. Although differences exist in the patterning of action potentials invading oxytocin and vasopressin terminals during secretory demand they exhibit similarity in their secretory time course and in their susceptibility to block by various pharmacologic compounds when exposed to similar stimulus regimes ${ }^{5,25}$. This is not the case for all synaptosomal or mixed terminal preparations ${ }^{29}$. In the present study basal $\left[\mathrm{Ca}^{2+}\right]_{\mathrm{i}},\left[\mathrm{K}^{+}\right]$-stimulated changes in $\left[\mathrm{Ca}^{2+}\right]_{\mathrm{i}}$ and susceptibility to block of $\mathrm{Ca}^{2+}$ influx by the DHP nicardipine were similar in each of the terminals examined. Thus, vasopressin- and oxytocin-containing terminals are similar in that the $\mathrm{K}^{+}$-induced rise in $\left[\mathrm{Ca}^{2+}\right]_{i}$ is largely mediated by the DHP sensitive, L-type voltage-sensitive $\mathrm{Ca}^{2+}$ channels. This conclusion is supported by the recent description using patch-clamp methodology of two $\mathrm{Ca}^{2+}$ channel types present on these terminals which exhibit characteristics similar to $\mathrm{L}$ and $\mathrm{N}$ channel types ${ }^{13}$. The lack of a significant contribution by the $\mathrm{N}$ type channel to the rise in $\left[\mathrm{Ca}^{2+}\right]_{i}$ by a 0.5 -min elevated $\left[\mathrm{K}^{+}\right]$pulse is supported by the rapid rate of decay $(10-20 \mathrm{~ms})$ of $\mathrm{Ca}^{2+}$ current carried through these channels at membrane potentials greater than $-10 \mathrm{mV}$. These resuls differ from those of some synaptosomal preparations where DHPs have little effect on $\mathrm{K}^{+}$-induced ${ }^{45} \mathrm{Ca}^{2+}$ influx or trans- 
mitter secretion ${ }^{28,32}$ although in some cases sensitivity to DHPs has been observed ${ }^{33}$. Furthermore, synaptosomal preparations generally show a fast phase of calcium entry that terminates within seconds which is attributed to voltage-sensitive $\mathrm{Ca}^{2+}$ channels that rapidly inactivate ${ }^{19}$. The maintenance of the $\mathrm{K}^{+}$-induced increase in $\left[\mathrm{Ca}^{2+}\right]_{\mathrm{i}}$ for the duration of the $\mathrm{K}^{+}$pulse, in the present study, suggests that in these neurosecretory terminals depolarization induced $\mathrm{Ca}^{2+}$ influx is maintained. The likelihood of $\mathrm{Na}^{+} / \mathrm{Ca}^{2+}$ exchange to maintain the $\mathrm{Ca}^{2+}$ influx under depolarizing conditions as suggested for some synaptosomal preparations ${ }^{22}$ is unlikely based on the observation of a similar $\mathrm{K}^{+}$-induced rise in $\left[\mathrm{Ca}^{2+}\right]_{i}$ in $\mathrm{Na}^{+}$-free medium. Clearly the contribution of various voltagesensitive $\mathrm{Ca}^{2+}$ channel types and of their influence on secretion may vary with the nerve ending type.

Relaxin, CCK and leucine enkephalin have been suggested to exert regulatory influences on vasopressin and oxytocin secretion at the level of the nerve endings by affecting $\left[\mathrm{Ca}^{2+}\right]_{i}^{3,8,24}$. However, in the present study, none of these peptides were found to affect either basal $\left[\mathrm{Ca}^{2+}\right]_{\mathbf{i}}$ or $\mathrm{K}^{+}$-stimulated increases in $\left[\mathrm{Ca}^{2+}\right]_{\mathrm{i}}$. These results are especially interesting for $\mathrm{CCK}$ which is co-localized ${ }^{16}$ and released ${ }^{15}$ with oxytocin and whose effects have been suggested to play a local rather than hormonal role based on a molar concentration of CCK in the rat neural lobe several orders of magnitude less than oxytocin. Additionally, a recent report showed CCK to potently induce secretion of both oxytocin and vasopressin in the absence of either electrical or $\mathrm{K}^{+}$-induced depolarization and independent of medium $\mathrm{Ca}^{2+}$ thus suggesting its actions may be mediated by mobilization of intracellularly stored $\mathrm{Ca}^{2+}$ (ref. 3). The results of the

\section{REFERENCES}

1 Augustine, G.J. and Eckert, R., Divalent cations differentially support transmitter release at the squid synapse, J. Physiol., 346 (1984) 257-271.

2 Bean, B.P., Two kinds of calcium channels in canine atrial cells. Differences in kinetics, selectivity and pharmacology, J. Gen. Physiol., 86 (1985) 1-30.

3 Bondy, C.A., Jensen, R.T., Brady, L.S. and Gainer, H., Cholecystokinin evokes secretion of oxytocin and vasopressin from rat neural lobe independent of external calcium, Proc. Natl. Acad. Sci. U.S.A., 86 (1989) 5188-5201.

4 Brethes, D., Dayanithi, G., Letellier, L. and Nordmann, J.J., Depolarization-induced $\mathrm{Ca}^{2+}$ increase in isolated neurosecretory nerve terminals measured with fura-2, Proc. Natl. Acad. Sci. U.S.A., 84 (1987) 1439-1443.

5 Cazalis, M., Dayanithi, G. and Nordmann, J.J., Hormone release from isolated nerve endings of the rat neurohypophysis, J. Physiol., 390 (1987) 55-70.

6 Charlton, M.P., Smith, S.J. and Zucker, R.S., Role of presynaptic calcium ions and channels in synaptic facilitation and depression at the squid giant synapse, J. Physiol., 323 (1982) 173-193.

7 Connor, J.A., Digital imaging of free calcium changes and of spatial gradients in growing processes in single, mammalian present study would suggest either that CCK exerts its stimulatory effects via a messenger pathway other than $\mathrm{Ca}^{2+}$ or its effects occur secondarily resulting from actions on glia or pituicytes. These latter cell types are largely missing in the isolated terminal preparation. Oxidation and hence reduction of biologic activity of the CCK peptide cannot explain the lack of effect as utilizing identical methodology results, at $1 \mathrm{nM} \mathrm{CCK}$, in near maximal mobilization of intracellular calcium in isolated pancreatic acini ${ }^{31}$. The effects of fura- 2 loading alone on the ability of the above peptides to modulate secretion has not been tested although heavier fura- 2 loading of the isolated terminals has previously found no reduction in elevated $\left[\mathrm{K}^{+}\right]$induced vasopressin secretion ${ }^{4}$. While these results do not rule out a regulatory influence of any of these peptides they strongly suggest their actions do not include direct effects on $\mathrm{Ca}^{2+}$ influx mediated via DHP-sensitive $\mathrm{Ca}^{2+}$ channels, or mobilization of $\mathrm{Ca}^{2+}$ from intraterminal stores. While the effects of enkephalin on release have been primarily studied on intact isolated neural lobes the effects of both relaxin and $\omega$-conotoxin have been documented on the isolated nerve endings. The kinetic limitations of this study preclude conclusions related to the possible modulatory effects of enkephalin or relaxin or of blocking effects of $\omega$-conotoxin on $\mathrm{Ca}^{2+}$ influx via $\mathrm{N}$-type $\mathrm{Ca}^{2+}$ channels. It is also possible that the modulatory effects of enkephalin and relaxin occur independently of $\left[\mathrm{Ca}^{2+}\right]_{\mathrm{i}}$ regulation. The lack of effect of $\omega$-conotoxin on the $\mathrm{K}^{+}$-evoked rise in $\left[\mathrm{Ca}^{2+}\right]_{i}$ in this study, but effective block by the L-type DHP $\mathrm{Ca}^{2+}$ channel blocker nicardipine, suggests there may be differential susceptibility to block by $\omega$-conotoxin among DHP-sensitive $\mathrm{Ca}^{2+}$ channels in excitable cell types.

central nervous system cells, Proc. Natl. Acad. Sci. U.S.A., 83 (1986) 6179-6183.

8 Dayanithi, G., Cazalis, M. and Nordmann, J.J., Relaxin affects the release of oxytocin and vasopressin from the neurohypophysis, Nature, 325 (1987) 813-816.

9 Dayanithi, G., Martin-Moutot, N., Barlier, S., Colin, D.A., Kretz-Zaepfel, M., Couraud, F. and Nordmann, J.J., The calcium channel antagonist $\omega$-conotoxin inhibits secretion from peptidergic nerve terminals, Biochem. Biophys. Res. Commun., 156 (1988) 255-262.

10 Fox, A.P., Nowycky, M.C. and Tsien, R.W., Single-channel recordings of three types of calcium channels in chick sensory neurones, J. Physial., 394 (1987) 173-200.

11 Grynkiewicz, G., Poenie, M. and Tsien, R.Y., A new generation of $\mathrm{Ca}^{2+}$ indicators with greatly improved fluorescence properties, J. Biol. Chem., 260 (1985) 3440-3450.

12 Komulainen, H. and Bondy, S.C., The estimation of free calcium within synaptosomes and mitochondria with fura-2; comparison to quin-2, Neurochem. Int., 10 (1987) 55-64.

13 Lemos, J.R. and Nowycky, M.C., Two types of calcium channels coexist in peptide-releasing vertebrate nerve terminals, Neuron, 2 (1989) 1419-1426.

14 Llinas, R., Steinberg, I.Z. and Walton, K., Presynaptic calcium currents and their relation to synaptic transmission: voltage clamp study in squid giant synapse and theoretical model for the 
calcium gate, Proc. Natl. Acad. Sci. U.S.A., 73 (1976) 29182922.

15 Marley, P.D., Lightman, S.L., Forsling, M.L., Todd, K., Goedert, M., Rehfeld, J.F. and Emson, P.C., Localization and actions of cholecystokinin in the rat pituitary neurointermediate lobe, Endocrinology, 114 (1984) 1902-1911.

16 Martin, R., Geis, R., Holl, R., Schafer, M. and Voight, K.H., Co-existence of unrelated peptides in oxytocin and vasopressin terminals of rat neurohypophyses: immunoreactive methionineenkephalin-, leucine-enkephalin- and cholecystokinin-like substances, Neuroscience, 8 (1983) 213-227.

17 Miledi, R. and Parker, I., Calcium transients recorded with arsenazo III in the presynaptic terminal of the squid giant synapse, Proc. R. Soc. Lond. Ser. B., 212 (1981) 197-211.

18 Miller, R.J., Multiple calcium channels and neuronal function, Science, 235 (1987) 46-52.

19 Nachshen, D.A., The early time course of potassium-stimulated calcium uptake in presynaptic terminals isolated from rat brain, J. Physiol., 361 (1985) 251-268.

20 Nachshen, D.A., Regulation of cytosolic calcium concentration in presynaptic nerve endings isolated from rat brain, $J$. Physiol., 363 (1985) 87-101.

21 Nachshen, D.A. and Blaustein, M.P., Influx of calcium, strontium and barium in presynaptic nerve endings, J. Gen. Physiol., 79 (1982) 1065-1087.

22 Nachshen, D.A. and Kongsamut, S., 'Slow' $\mathrm{K}^{+}$-stimulated $\mathrm{Ca}^{2+}$ influx is mediated by $\mathrm{Na}^{+}-\mathrm{Ca}^{2+}$ exchange: a pharmacological study, Biochem. Biophys. Acta, 979 (1989) 305-310.

23 Nachshen, D.A. and Sanchez-Armass, S., Co-operative action of calcium ions in dopamine release from rat brain synaptosomes, J. Physiol., 387 (1987) 415-423.

24 Nordmann, J.J., Dayanithi, G. and Cazalis, M., Do opioid peptides modulate, at the level of the nerve endings, the release of neurohypophyseal hormones?, Exp. Brain Res., 61 (1986) $560-566$.

25 Nordmann, J.J., Desmazes, J.P. and Georgescault, D., The relationship between the membrane potential of neurosecretory nerve endings, as measured by a voltage-sensitive dye, and the release of neurohypophysial hormones, Neuroscience, 7 (1982) 731-737.

26 Nowycky, M.C., Fox, A.P. and Tsien, R.W., Three types of neuronal calcium channel with different calcium agonist sensitivity, Nature, 316 (1985) 440-442.

27 Ohta, M., Narahashi, T. and Keeler, R.F., Effects of veratrum alkaloids on membrane potential and conductance of squid and crayfish giant axons, J. Pharmacol. Exp. Ther., 184 (1973) 143-154.

28 Reynolds. I.J., Wagner, J.A., Snyder, S.H., Thayer, S.A., Olivera, B.M. and Miller, R.J., Brain voltage-sensitive calcium channel subtypes differentiated by $\omega$-conotoxin fraction GVIA, Proc. Natl. Acad. Sci. U.S.A., 83 (1986) 8804-8807.

29 Stuenkel, E.L. and Cooke, I.M., Electrophysiological characteristics of peptidergic nerve terminals correlated with secretion. In D. Ganten and D. Pfaff (Eds.), Current Topics in Neuroendocrinology, Stimulus-Secretion Coupling in Neuroendocrine Systems, Vol. 9, Springer, New York, 1988, pp. 123-150.

30 Stuenkel, E.L. and Ernst, S.A., Multiple calcium mobilization pathways in single avian salt gland cells, Am. J. Physiol., 258 (1990) C289-C298.

31 Stuenkel, E.L., Tsunoda, Y. and Williams, J.A., Secretagogue induced calcium mobilization in single pancreatic acinar cells, Biochem. Biophys. Res. Commun., 158 (1989) 863-869.

32 Suszkiw, J.B., Marawsky, M.M. and Fortner, R.C., Further characterization of phasic calcium influx in rat cerebrocortical synaptosomes: inferences regarding calcium channel type(s) in nerve endings, Biochem. Biophys. Res. Commun., 145 (1987) 1283-1286.

33 Turner, T.J. and Goldin, S.M., Calcium channels in rat brain synaptosomes: identification and pharmacological characterization, J. Neurosci., 5 (1985) 841-849.

34 Verhage, M., Besselsen, E., Lopes Da Silva, F.H. and Ghigsen, W.E.J.M., Evaluation of the $\mathrm{Ca}^{2+}$ concentration in purified nerve terminals: relationship between $\mathrm{Ca}^{2+}$ homeostasis and synaptosomal preparation, J. Neurochem., 51 (1988) 1667-1674. 